\title{
Implementation of Visual Audio Media in Increasing Learning Interest of Students in SD IT Luqman AI Hakim
}

\author{
Ni'mal Chitam \\ SDIT Luqman Al Hakim Kudus \\ chit.tham88@gmail.com
}

\section{Article History}

accepted 01/11/2020

approved 08/11/2020

published 15/11/2020

\begin{abstract}
The purpose of this study was to increase students' interest in learning thematic learning in grade VI elementary schools using audio-visual media. This research is a classroom action research (PTK) which is carried out in three cycles, each cycle consisting of stages planning, implementing, observing, and reflecting. The subjects of this research are students of class VI SDIT Luqman Al Hakim Kudus for the 2020/2021 academic year totaled 19 students. Data collection techniques using observation and test. Data analysis includes data reduction, data presentation, and drawing conclusions. Research shows that the implementation of audio visual media can increase student interest in thematic learning in class VI SDIT Luqman Al Hakim Kudus for the 2020/2021 academic year as evidenced by the percentage of interest in learning in cycle I of $37 \%$ to $53 \%$ in cycle II. And to $89 \%$ on cycle 3 .
\end{abstract}

Keywords: learning interests, audio visual media

\section{Abstrak}

Tujuan penelitian ini adalah meningkatkan minat belajar siswa pada pembelajaran Tematik di sekolah dasar kelas VI dengan media audio visual. Penelitian ini merupakan penelitian tindakan kelas (PTK) yang dilaksanakan dalam tiga siklus, setiap siklus terdiri dari tahap perencanaan, pelaksanaan, observasi, dan refleksi. Subjek penelitian ini adalah peserta didik kelas VI SDIT Luqman Al Hakim Kudus tahun pelajaran 2020/2021 yang berjumlah 19 peserta didik. Teknik pengumpulan data menggunakan observasi dan tes. Analisis data meliputi reduksi data, penyajian data, dan penarikan kesimpulan. Penelitian menunjukkan bahwa implementasi media audio visual dapat meningkatkan minat belajar siswa pada pembelajaran Tematik di kelas VI SDIT Luqman Al Hakim Kudus tahun pelajaran 2020/2021 yang dibuktikan dengan persentase minat belajar pada siklus I sebesar 37\% menjadi 53\% pada siklus II. Dan menjadi $89 \%$ pada siklus 3.

Kata kunci: minat belajar, media audio visual

Social, Humanities, and Education Studies (SHEs): Conference Series https://jurnal.uns.ac.id/shes 


\section{PENDAHULUAN}

Pendidikan bagi kehidupan manusia merupakan kebutuhan mutlak yang harus dipenuhi sepanjang waktu. Fuad Ihsan (2005) berpendapat bahwa tanpa pendidikan mustahil sekelompok manusia dapat berkembang sejalan dengan aspirasi (cita-cita) untuk maju, sejahtera dan bahagia menurut konsep pandangan hidup mereka. untuk memajukan kehidupan mereka itulah, maka pendidikan merupakan sarana yang harus dikelola, secara sistematis, dan konsisten berdasarkan berbagai pandangan teorikal dan praktikal sepanjang waktu sesuai dengan lingkungan hidup manusia itu sendiri. Sarana, prasarana dan fasilitas fisik juga sangat mendukung berlangsungnya proses belajar mengajar yang efektif. Kondisi belajar mengajar yang efektif adalah adanya minat dan perhatian siswa dalam belajar. Minat merupakan suatu sifat yang relative menetap pada diri seseorang. Minat ini besar sekali pengaruhnya, sebab dengan minat seseorang akan melakukan sesuatu yang diminatinya. Sebaliknya, tanpa minat seseorang tidak mungkin melakukan sesuatu. Misalnya seseorang akan menaruh minat terhadap bidang Tematik, maka dia akan berusaha untuk mengetahui lebih banyak tentang Tematik.

Ada beberapa definisi mengenai minat belajar yang telah dipaparkan oleh para ahli. Beberapa diantaranya menjelaskan bahwa minat belajar merupakan suatu rasa untuk menyukai atau tertarik pada suatu hal atau aktivitas belajar tanpa ada yang menyuruh (Slameto, 2010). Minat belajar juga didefinisikan sebagai keinginan dan keterlibatan yang disengaja dalam aktivitas kognitif yang memainkan bagian penting dalam proses pembelajaran, menentukan bagian apa yang kita pilih untuk belajar, dan seberapa baik kita mempelajari informasi yang diberikan (Klassen \& Klassen, 2014). Marimba (1980, dalam Kpolovie, Joe, \& Okoto, 2014) mengungkapkan bahwa minat belajar adalah kecenderungan jiwa untuk mendapatkan sesuatu karena siswa tersebut merasakan hal yang menarik dalam belajar, yang umumnya ditandai dengan perasaan senang. Adapun menurut Renninger, Hidi, \& Krapp (2014), minat belajar adalah sebuah fenomena yang muncul dari interaksi individu dengan lingkungannya. Hal senada pun diungkapkan oleh Krapp (2000) dan Renninger \& Hidi (2011), dalam Kiemer, Groschner, \& Pehmer (2015) bahwa minat adalah kecenderungan seseorang untuk terlibat secara berulang atau perhatiannya terfokus pada objek, yang ditentukan oleh hubungan khusus antara orang dan objek dan dibentuk oleh interaksi dengan lingkungan. Minat belajar pun didefinisikan sebagai pembangun motivasi yang mengacu pada keinginan dan kenikmatan siswa untuk terlibat dalam tugas-tugas serta keinginan untuk memperoleh pengetahuan (Hidi \& Renninger, 2006, dalam Sha, Schunn, Bathgate, \& Ben-Eliyahu, 2016).

Minat dan motivasi belajar adalah dua faktor psikologis yang telah banyak dibuktikan secara empiris memiliki pengaruh yang signifikan terhadap prestasi akademik siswa di sekolah (Kpolovie, Joe, \& Okoto, 2014). Siswa yang memiliki minat dan motivasi belajar yang tinggi biasanya ditandai dengan nilai akademik yang baik, memiliki kebiasaan belajar yang terstruktur, memiliki pemahaman yang baik terhadap setiap bacaan (Silvia, 2012, dalam Black \& Allen, 201 6), memiliki efikasi diri yang tinggi, serta memiliki kinerja belajar yang tinggi (Tang \& Reynolds 1993, dalam Howard, Tang, \& Austin, 2014). Adapun siswa yang memiliki minat dan motivasi belajar yang rendah, biasanya memiliki kecenderungan untuk menarik diri, tidak masuk sekolah, putus sekolah, memiliki rasa cemas yang relatif tinggi, serta memiliki hasil akademik yang rendah (Prospero \& Vohra, 2007 dalam Sturges, Maurer, Allen, Gatch, \& Shankar, 2016). 
Berdasarkan hasil interview peneliti dengan siswa, minat dan perhatian siswa terhadap pelajaran Tematik sangat kurang. Dalam proses belajar mengajar materi Tematik, seorang guru diberlakukan ibarat radio rusak yang tidak diperhatikan. Hal ini dibuktikan dengan adanya indikasi bahwa, siswa berperilaku yang tidak sesuai dengan peraturan atau etika kelas. Seperti mengobrol dengan teman, tidur, melamun dan sebagainya. Berdasarkan hasil observasi, ternyata perilaku-perilaku siswa yang menyalahi etika-etika kelas disebabkan oleh kurangnya minat belajar. Kurangnya minat belajar siswa salah satunya adalah karena guru masih mengajar dengan cara konvensional misalnya ceramah. Oleh karena itu menurut peneliti hal ini perlu diteliti, bagaimana caranya untuk bisa membangkitkan minat siswa dalam belajar. Banyak cara yang bisa digunakan untuk membangkitkan minat siswa. Media pembelajaran yang inovatif dan kreatif umumnya mampu meningkatkan minat belajar siswa melalui penyajian dan penyampaian materi secara menarik (Prawiro, 2012). Media dapat berupa audio, visual atau gabungan dari keduanya yakni audio-visual.

Media yang tepat digunakan untuk membantu guru dalam meningkatkan minat belajar yaitu salah satunya dengan menggunakan media audiovisual. Penggunaan media ini dapat mengoptimalkan hasil belajar siswa karena media ini bisa dilihat dan didengar serta siswa bisa lebih fokus terhadap pembelajaran yang disampaikan oleh guru. Mengingat tipe tanggapan siswa berbeda-beda ada yang bisa cepat mengerti lewat mendengar, ada yang mengerti dengan melihat saja, atau ada juga yang bisa mengerti dengan mendengar dan melihat. Penggunaan media audiovisual siswa diupayakan mampu merelevansikan pengetahuan-pengetahuan yang ada dengan pengalaman-pengalaman yang dilihat atau yang dirasakannya sehingga belajar terasa lebih berkesan bagi siswa (Armah, 2013). Media (audio visual) dapat membangkitkan keinginan dan minat yang baru. Dengan menggunakan media (audio visual), horizon pengalaman anak semakin luas, persepsi semakin tajam, dan konsep-konsep dengan sendirinya semakin lengkap, Sehingga keinginan dan minat baru untuk belajar selalu timbul (Azhar Arsyad:2011).

Martinis Yamin \& Bansu I. Ansari (2009), bahwa dengan media pembelajaran (audio visual), proses belajar-mengajar menjadi lebih menarik. Hal ini dapat meningkatkan minat dan apresiasi peserta didik terhadap ilmu pengetahuan dan proses pencarian ilmu itu sendiri. Bacthiar (2013) menjelaskan bahwa media audiovisual dapat memperjelas penyajian pesan agar tidak terlalu bersifat verbalistis. Media audiovisual dapat membantu guru dalam menyampaikan informasi diluar jangkauan namun dapat disajikan secara konkret. Adapun kelebihan dari media audio visual menurut Sadiman (dalam Trisnadewi, 2014) yaitu: (1) dapat digunakan untuk klasikal atau individual, (2) dapat digunakan seketika, (3) digunakan secara berulang, (4) dapat menyajikan materi secara fisik jika tidak dapat bicara ke dalam kelas, (5) dapat menyajikan objek yang bersifat bahaya, (6) dapat menyajikan objek secara detail, (7) tidak memerlukan ruang gelap, (8) dapat di perlambat dan di percepat, dan (9) menyajikan gambar dan suara. Media audio-visual disebut juga sebagai media video. Video merupakan media yang digunakan untuk menyampaikan pesan pembelajaran (Waryanto, 2007). Thomson (2014) menyatakan video menepatkan diri pada paradigma konstruktivis yang berpusat pada siswa dan bukan yang mentranstruksikan melalui penciptaan lingkungan belajar pemecahan masalah atau penyelidikan. Pengalaman-pengalaman yang diberikan dalam pembelajaran dengan bantuan media audiovisual akan mengajak 
Berdasarkan latar belakang tersebut, penelitian ini akan mencari pengaruh media audio visual terhadap minat belajar siswa jenjang sekolah dasar, dengan mengambil objek penelitian kelas VI. Sehingga Penulis melakukan penelitian yang berjudul "Implementasi Media Audio Visual Dalam Meningkatkan Minat Belajar Siswa Kelas 6 Sdit Luqman Al Hakim Kudus Pembelajaran Tematik 5 Subtema 1 Pembelajaran 3 Semester Ganjil Tahun Pelajaran 2020/2021".

\section{METODE}

Penelitian ini merupakan penelitian tindakan kelas (PTK) kolaboratif yang dilaksanakan dalam tiga siklus, setiap siklus terdiri dari tahap perencanaan, pelaksanaan, observasi, dan refleksi. Subjek penelitian ini adalah peserta didik kelas VI SDIT Luqman Al Hakim Kudus tahun pelajaran 2020/2021 yang berjumlah 19 peserta didik. Analisis penelitian ini adalah analisis deskriptif kuantitafif kualitatif dimana dalam penelitian ini selain penyajian hasil berupa data maupun angka peneliti juga menentukan bagaimana cara pengolahan hasil penelitian yakni dengan membuat analisisnya dengan menerapkan media audio visual. Teknik pengumpulan data yang dilakukan dengan observasi dan kuesioner. Observasi meliputi aktivitas siswa dalam kegiatan pembelajaran. Untuk minat belajar menggunakan kuesioner.

\section{HASIL DAN PEMBAHASAN}

Hasil penelitian menunjukkan peningkatan minat belajar siswa pada materi Tematik. Terlihat pada tabel berikut.

\begin{tabular}{|c|c|c|c|c|}
\hline \multirow{2}{*}{ Siklus } & \multicolumn{2}{|c|}{ Siswa Kurang Berminat } & \multicolumn{2}{|c|}{ Siswa Berminat } \\
\hline & Jumlah & Persentase & Jumlah & Persentase \\
\hline $\mathrm{I}$ & 12 & $63 \%$ & 7 & $37 \%$ \\
\hline II & 9 & $47 \%$ & 10 & $53 \%$ \\
\hline III & 2 & $11 \%$ & 17 & $89 \%$ \\
\hline
\end{tabular}

Pada pelaksanaan pembelajaran siklus I peneliti memperoleh hasil kuesioner minat belajar siswa dalam tematik tema 5 subtema 1 pembelajaran 1 kurang. Yaitu hanya 7 (37\%) siswa yang beminat, sedangkan 12 (63\%) siswa kurang berminat. Kenyataan tersebut mendorong peneliti untuk merefleksi dan mencari kekurangan yang selama ini terjadi. Hasil refleksi inilah yang kemudian menjadi titik tolak untuk mengadakan perbaikan dengan menggunakan media audio visual. Pada pelaksanaan siklus II hasil kuesioner minat belajar menunjukkan adanya peningkatan. Yaitu dari 7 $(37 \%)$ siswa yang beminat menjadi 10 (53\%) siswa yang beminat. Dari hasil pengamatan yang dilakukan observer juga menujukkan bahwa keaktifan dan kualitas belajar siswa meningkat mencapai kategori baik. Guru dan siswa lebih semangat selama kegiatan pembelajaran berlangsung. Siswa tidak hanya sebagai penerima informasi, tetapi juga terlibat langsung dalam mencari dan member informasi baik dengan guru maupun teman sebaya melalui diskusi dan tanya jawab.

Pada pelaksanaan siklus III hasil kuesioner minat belajar juga menunjukkan adanya peningkatan yang signifikan. Yaitu dari 10 (53\%) siswa yang beminat pada siklus II, menjadi 17 (89\%) siswa yang berminat. Dari hasil pengamatan yang dilakukan observer juga menujukkan bahwa keaktifan dan kualitas belajar siswa meningkat mencapai kategori sangat baik. Guru dan siswa lebih semangat selama kegiatan pembelajaran berlangsung. Siswa tidak hanya sebagai penerima informasi, tetapi juga terlibat langsung dalam mencari dan memberi informasi baik dengan guru maupun teman sebaya melalui diskusi dan tanya jawab. Dari tiga siklus yang sudah dilaksanakan selama 3 pertemuan dapat dipastikan bahwa media audio visual dapat meningkatkan minat belajar siswa pada materi Tematik Kelas VI di SDIT Luqman AI 
Hakim Kudus. Hal ini sesuai dengan teori yang diungkapkan oleh Martinis Yamin \& Bansu I. Ansari (2009), bahwa dengan media pembelajaran (audio visual), proses belajar-mengajar menjadi lebih menarik. Hal ini dapat meningkatkan minat dan apresiasi peserta didik terhadap ilmu pengetahuan dan proses pencarian ilmu itu sendiri.

Disamping itu juga sebagaimana disampaikan oleh Azhar Arsyad (2011) Media (audio visual) dapat membangkitkan keinginan dan minat yang baru. Dengan menggunakan media (audio visual), horizon pengalaman anak semakin luas, persepsi semakin tajam, dan konsep-konsep dengan sendirinya semakin lengkap, Sehingga keinginan dan minat baru untuk belajar selalu timbul. Maka sekali lagi bisa dipastikan bahwa implementasi media audio visual dapat meningkatkan minat belajar siswa, sehingga kelas menjadi hidup dan interaktif.

\section{SIMPULAN}

Berdasarkan hasil penelitian dan uraian pembahasan maka dapat diambil simpulan sebagai berikut. Implementasi media audio visual dapat meningkatkan minat belajar siswa pada materi Tematik di kelas VI SDIT Luqman AI Hakim Kudus tahun pelajaran 2020/2021 yang dibuktikan dengan rata-rata minat belajar peserta didik pada siklus I sebesar 37\%, meningkat menjadi 53\% pada siklus II. Dan meningkat lagi menjadi $89 \%$ pada siklus III.

\section{DAFTAR PUSTAKA}

Armah. 2013. Pengaruh Media Audiovisual Terhadap Kemampuan Menulis Teks Berita Oleh Siswa Kelas VIII SMP PGRI 9 Percut Sei Tuan Tahun Pembelajaran 2012/2013. Universitas Negeri Medan (Vol: 3 Tahun 2013)

Arsyad, Azhar, Media Pembelajaran, Jakarta: PT. Raja Granfindo Persada, 2011.

Bacthiar, Chamdani Lukman. 2013. Media Pembelajaran Audiovisual Terhadap Pembelajaran Lompat Jauh Pada siswa Kelas IV SD N Grobogan 4 Kabupaten Grobogan Tahun Ajaran 2013/2014. Universitas Negeri Semarang

Black, S., \& Allen, J. D. (2016). Part 1: Foster Intrinsic Motivation. The Reference Librarian, 1-16.

Howard, L. W., Tang, T. L.-P., \& Austin, M. J. (2014, February 16). Teaching Critical Thinking Skills: Ability, Motivation, Intervention, and The Pygmalion Effect. Journal of Business Ethics , 1-15.

Ihsan, Fuad, Dasar-Dasar kependidikan, Rineka Cipta, Jakarta, 2005

Klassen, S., \& Klassen, C. F. (2014). The Role of Interest in Learning Science Through Stories. Interchange , 1-19.

Kpolovie, P. J., Joe, A. I., \& Okoto, T. (2014). Academic Achievement Prediction: role of Interest in Learning and Attitude Towards School. International Journal of Humanities Social Sciences and Education, 1 (11), 73-100.

Prawiro, S. A., dan Irawan, A. H. 2012. Perencanaan Media Pembelajaran Interaktif Ilmu Pengetahuan Alam untuk Siswa Kelas 4 dengan Metode Learning The Actual Object. Jurnal Sains dan Seni ITS, 1 (1):28-33.

Renninger, K. A., Hidi, S., \& Krapp, A. (2014). The Role of Interest in Learning and Development. London: Psychology Press.

Slameto. (2010). Belajar dan Faktor-Faktor yang Mempengaruhinya. Jakarta : Rineka Cipta

Sturges, D., Maurer, T. W., Allen, D., Gatch, D. B., \& Shankar, P. (2016). Academic Performance in Human Anatomy and Physiology Classes: A 2 Year Study of Academic Motivation and Grade Expectation. Advances Psychology Education , 26-31. 
Thomson, Andrew. "Teacher Flipping Out" Beyond The online Lecture: Maximing the Ecucational Potencial of Video. Quesland University Of echnology, Australia (Vol: 7 No: 3)

Yamin, Martinis, Bansu I. Ansari, Taktik Mengembangkan Kemampuan Individual Peserta Didik, Jakarta: Gaung Persada Press, 2009. 